\title{
Allogeneic Melanoma Vaccine AGI-101H
}

National Cancer Institute

\section{Source}

National Cancer Institute. Allogeneic Melanoma Vaccine AGI-101H. NCI Thesaurus. Code C78861.

A cancer vaccine derived from two gentically modified human melanoma cell lines with potential antineoplastic activity. Allogeneic melanoma vaccine AGI-101H consists of a 1:1 mixture of cells from two genetically modified human melanoma cell lines, designated as Mich1 H6 and Mich2 H6, that have been gamma-irradiated to render the cells nonproliferative. Upon administration, this vaccine may stimulate a cytotoxic immune response against melanoma tumor cells. 